\title{
ASSESSMENT OF THE AGRARIAN LANDSCAPE STRUCTURE IN THE DEVELOPMENT AREA OF THE MAJOR CITIES OF LITHUANIA
}

Jolanta VALČIUKIENĖ, Institute of Land Management and Geomatics, Faculty of Water and Land Management, Vytautas Magnus University, K. Donelaicio str. 58, 44248 Kaunas, Lithuania, jolanta.valciukiene@ vdu.lt (corresponding author)

Daiva JUKNELIENĖ, Institute of Land Management and Geomatics, Faculty of Water and Land Management, Vytautas Magnus University, K. Donelaicio str. 58, 44248 Kaunas, Lithuania, daiva.jukneliene@ vdu.lt

Virginija ATKOCEVIČIENĖ, Institute of Land Management and Geomatics, Faculty of Water and Land Management, Vytautas Magnus University, K. Donelaicio str. 58, 44248 Kaunas, Lithuania, virginija.atkoseviciene@ vdu.lt

\begin{abstract}
Agrarian landscape structure in Lithuania is relatively stable and changes only due to intensive economic activities such as construction of buildings, land reclamation, and afforestation. The changes due to the aforementioned activities are most evident in the development areas of the major cities, which are characterized by the increasing process of chaotic urbanization. The suburban municipalities, bordering the three major cities of Lithuania (Kaunas, Vilnius, Klaipeda), were chosen for the research. To determine areas that were influenced by the urban development among the analyzed cities, the multicriteria analysis method was chosen, which helped to assess the intensity of the suburban area development. The determined areas, which were influenced by the urban development, were divided into three categories, in which the villages of 583 agrarian territories are included. The greatest influence of the urban development on the agrarian landscape is evident in the territories that are closest to the major cities (in the areas of category I) and in which the structure of the components of the agrarian landscape changes mostly by reducing the agricultural land. To ensure a balanced influence of urban development on the agrarian landscape, the average built-up area in the development area of the major cities should not be higher than $20 \%-30 \%$ and the agricultural land area should not be lower than $30 \%-45 \%$. To preserve the fertile land, the built-up areas should be designed in the agricultural lands with lower productivity.
\end{abstract}

Keywords: agrarian landscape, suburban areas, sustainable urban development

\section{INTRODUCTION}

The process of urbanization has been unceasingly changing the landscape of all countries over the world. The most interesting, complex, urban development process that covers large areas is suburbanization (the development of the suburbs and suburban areas). On the one hand, the town is accumulating the adjacent territories (suburbs) very quickly. Conversely, the suburbs rapidly cover larger areas of the agrarian territories and change the land use completely. Scientific literature, analyzing evolution and peculiarities of suburbanization processes, suburban zone structure as well as functional and typological structure suggests that suburban areas usually have higher density of rural population and intensity of urbanized territory, expressed as a percentage of the general size of residential area in hectares and relatively higher average agricultural land market value in relation to better opportunities of the use of these territories for various activities (residential, commercial construction, etc.), and a relatively shorter distance to the city center (Adell, 2016; Charter..., 2016; Cesnavicius, 1999; Masotti, 1991; Kostof, 1992; Meeus \& Gulinck, 2008; Vaughan et.al., 2009).

Foreign scholars who initiated the investigation of the evolution and characteristics of suburbanization processes a few decades ago published an abundance of papers on the subject. Countries of Northern America and Western Europe are the most advanced in the field (Andrews, 1986; Baumeister, 2006; Berger, 2006; Mumford, 1968; Clawson, 1971; Jackson, 1985).

A lot of research have been devoted to the structural, functional, and typological analysis of suburban areas (Hall, 2002; Cesnulevicius at al., 2005; Frey, 2007).

Discussions on suburban areas in respect of territorial extent, systems of local settlements, central cities, or other points of view are still relevant (Cowan, 2005; Hornis \& Van Eck, 2008; Daunora, 2010; Dijokiené, 2006; Wiese, 1997; Witherick et.al., 2001). Hence, the relation between suburbanization and counter-urbanization, their positive and negative features, and consequences have been investigated for several decades (Hoggart et al., 1998; Ilbery, 1998; Teaford, 1995; Bucas, 2005; Laukaitytè-Malzinskienè, 2005).

The subject of suburban area was highlighted in various studies of previous Lithuanian geographers, town planners, and economists. Significant, however, partial studies of suburban areas were conducted in the fields of the analysis of urbanization processes, economic and urban development (Daunora, 2003; Bucas, 2010; Juskevicius and Gauce 2010; Juskevicius et.al. 2009; Zagorskis, 2005), where the suburban area was also characterized in part.

Copyright $\odot 2019$ The Authors. Published by Vytautas Magnus University. This is an open-access article distributed under the terms of the Creative Commons Attribution License (CC BY 4.0), which permits unrestricted use, distribution, and reproduction in any medium, provided the original author and source are credited. 
Works of territorial planning related to the development of districts or regions were also conducted in respect of suburban areas. Some works stressed on the fact that suburban areas are like a protective green ring of large cities, thus preventing environmental disasters. For these purposes, ecological suburban areas were planned (Daujotaite, 1967).

The process of suburbanization is primarily and rapidly appearing in the major cities; however, it also affects smaller villages that are near the large city. Moreover, it becomes more and more difficult to determine the border between the rural and urban areas as it becomes variable and conditional. The influence of the urban functions on the suburban landscape occurs concentrically, i.e., by going farther from the city, the landscape has more features of rural areas - agrarian landscape. Between the elements, which change rapidly and have the greatest influence on the suburban landscape, the following are distinguished: built-up areas (villages, roads, etc.), undeveloped territories (natural territories, by distinguishing the recreational areas), and agricultural areas. The latter are mostly urbanized due to the uncoordinated and intensive development of the suburban areas, usually by violating the principles of the development of the suburban areas.

Thus, the aim of this work is to perform an assessment of the agrarian landscape structure in the development area of the major cities of Lithuania. It is expected that this assessment will help to deliver a fuller image of the process, which takes place in the suburban landscape; will provide opportunities to foresee the results of the current process of urbanization for the landscape more precisely; and will help to highlight certain elements of sustainable management of suburban areas.

\section{MATERIALS AND METHODS}

Mathematical and statistical, multi criteria, cartographic material, scientific literature analysis methods as well as comparative, graphical modeling, generalization and logical abstraction methods were used in this research.

By performing an experimental investigation, territories that are the closest to the three major cities of Lithuania Kaunas, Klaipeda, and Vilnius - were chosen. Other regions are small, and the urban development there is not intensive. Therefore, they are not of great significance to this investigation. The suburban municipalities that border the cities (joint border with the major cities) were chosen.

In order to select and evaluate the importance of suburban areas the multi-criteria analysis methods SAW (Simple Additive Weighting) and DEA (Data Envelopment Analysis) were used.

\section{SAW method}

SAW method is most widely known and practically used method, which belongs to the class of the MultipleCriteria Decision-Making (MCDM) methods (Saaty, 1980; Hwang \& Yoon, 1981; Chang et al., 2007;. Chen, 2009; Zavadskas \& Antucheviciene, 2007). Since the 1960s, MCDM has been an active area of research, is a generic term for all methods that exist for helping a decision makers making decisions according to their preferences, in cases where there is more than one conflicting criterion (Ho, 2008). MCDM is a model that allows the analysis of several preferences simultaneously. Methods provide an opportunity for determining the best alternative among the available options and ranking the alternatives based on their significance for a particular purpose (Salminen et. al., 1998). These methods have shown to be popular and widely used by researchers and practitioners.

The core of SAW method is the construction of so-called 2-dimensional evaluation matrix, where one dimension expresses the various alternatives and the other dimension the criteria by which the alternatives must be evaluated. Alternatives represent the different choices of action available to the decision maker. They are supposed to be screened, prioritized and eventually ranked. In this study the alternatives are the suburban residential areas (localities) (Kaunas-212 alternatives-localities, Klaipèda-152, Vilnius-294).

Each MCDM problem is associated with multiple criteria. The localities are characterized by the following criteria: density of the rural population; intensity of the urbanized territories, which is expressed as a percentage from the general residential area size in hectares; average market price of the land designated for agricultural purposes, which is related to the opportunities for the development of the land for the various activities (residential, commercial construction, and other); and distance to the city center. The value of criterion shows the state of alternative in one dimension. Also criterion indicates the direction of improvement (maximizing density of population, intensity of the urbanized territory, average market price of the land and minimizing distance to the city center consequently effects to become better urbanized state of the locality).

Decision problems involve criteria of varying importance to decision maker. Differences of importance of criteria are reflected by assigning weights of each criterion. There are many techniques commonly used for assessing the criterion weights such as ranking and rating methods, pairwise comparison and trade-off methods. Weights are obtained by eliciting opinions of decision makers directly or by processing matrix of criteria preferences (Saaty, 1980). Normalization of weights is a compulsory procedure in most of MCDM methods. Criteria weights $w_{i}$ must meet the following condition $\sum_{i=1}^{m} w_{i}=1$. Under the experts opinion the following criteria weights are established: density $w_{1}=0.3$; intensity $w_{2}=0.2$; land market price $w_{3}=0.3$; distance to city center $w_{4}=0.2$. For the purpose of this paper we stress that the idea of weighting means that exclusively weights are meant exclusively to reflect differences of criteria importance. This statement is either communicated to experts, who are asked to estimate the weights, or is implicitly understood by 
them. Consequently, weights enable the decision maker to take subjective standpoints within his selection process into account.

By considering the determined alternatives, criteria, their weights, the influence on the established aim, and the significance of the alternative areas according to the assessed criteria, the evaluation matrix $\boldsymbol{D}$ (Table 1), was created.

Table 1. Evaluation matrix $D$ of the locality data

\begin{tabular}{lcccccc}
\hline \multicolumn{1}{c}{ Title of the criterion } & Direction & Weight & Locality 1 & Locality 2 & $\ldots$. & Locality $_{\mathrm{m}}$ \\
\hline $\begin{array}{l}\text { Density of rural population, p/100 } \\
\text { ha }\end{array}$ & Max & 0.3 & 1.41 & 23.98 & 13.04 & 2.94 \\
\hline $\begin{array}{l}\text { Intensity of urban areas of the total } \\
\text { residential area size in percent }\end{array}$ & Max & 0.2 & 1.4 & 15.6 & 29.7 & 3.6 \\
\hline $\begin{array}{l}\text { The average value of the land } \\
\text { designated for agricultural } \\
\text { purposes, EUR/ha }\end{array}$ & Max & 0.3 & 11299 & 49250 & 84015 & 49250 \\
\hline Distance to the city center, km & Min & 0.2 & 16.2 & 14.7 & 12.3 & 19.1 \\
\hline
\end{tabular}

The element $d_{i j}$ of the matrix $\boldsymbol{D}$ of the locality data shows the value of the data unit of criterion $i$ in the locality $j$ $(i=1, \ldots, n ; j=1, \ldots, m)$. Here $n=4$ and $m$ is the number of localities. $(\mathrm{m}=212,152,294$ for Kaunas, Klaipeda and Vilnius, respectively). The data of criteria in the evaluation matrix have different dimensions and scale. It is necessary to normalize the value of the criteria data in order to eliminate the impact of the scales and dimensions for the final scores and ranking results of the alternatives. In many papers (Hwang \& Yoon, 1981; Zavadskas \& Kaklauskas, 1996; Figueira \& Roy, 2002; Chen, 2009) normalization (transformation) of initial data is used, i.e. that the best criterion value (largest for a maximizing criterion and smallest one for a minimizing criterion) would get largest value equal to unity. Therefore, the evaluation matrix $\boldsymbol{D}$ was transformed using three types of normalization (transformation): vector, linear, and the procedure of min-max.

Vector normalization formula (Voogd, 1983):

$$
r_{i j}=d_{i j} /\left|\vec{d}_{i}\right|
$$

Here $\quad\left|\vec{d}_{i}\right|=\sqrt{\sum_{j=1}^{m} d_{i j}^{2}} \quad-$ vector's magnitude. Normalized values are included in the interval $\left(\min _{j} d_{i j} /\left|\vec{d}_{i}\right| ; \max _{j} d_{i j} /\left|\vec{d}_{i}\right|\right)$. The $r_{i j}$ value is zero only when $d_{i j}$ value is zero. The unit value is practically obtained only when the data matrix has of only two values. In all other cases (as well as in the relevant case) the unit value of $r_{i j}$ is not obtained.

Linear scale transformation formula (Yoon \& Hwang, 1995).

$$
r_{i j}=d_{i j} / \max _{j} d_{i j} \text { (linear), }
$$

where $\max _{j} d_{i j}$ is the largest element value in the $i^{t h}$ criterion row. Moreover, it is the most straightforward realization equation according to which $r_{i j} \in(0 ; 1]$.

Min-max transformation formula (Figueira \& Roy, 2002):

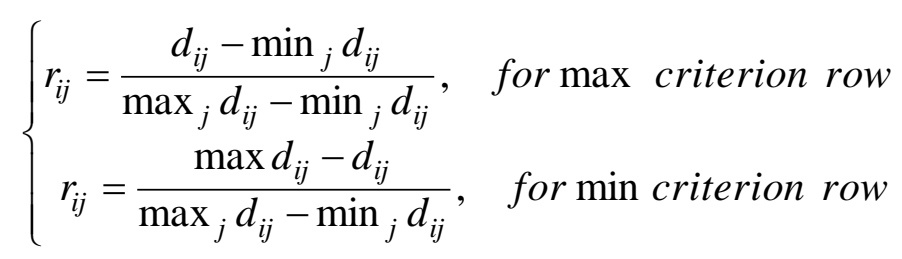

where $\min _{j} d_{i j}$ is the smallest value of the matrix $\boldsymbol{D}$ in the $i^{t h}$ criterion row. This equation is the most frequently applied in multi-criteria analysis and guarantees that all line values of matrix $\boldsymbol{D}$ are transformed into a closed interval $[0 ; 1]$, because $\max _{j} d_{i j} \rightarrow r_{i j}=1$ as well $\min _{j} d_{i j} \rightarrow r_{i j}=0$. 
Values of criteria characterizing each object are comprised into a single non-dimensional cumulative criterion, reflecting attractiveness of the object in view of a chosen objective of investigation or evaluation. There is a realm of methods of normalization available. Nevertheless, magnitudes of criteria are accounted differently using different transformation methods. Such an effect could be often treated as a distortion of data transformation, or illicit discrimination between criteria. Therefore, it is aimed that transformations used in the study retain the objective states of situations.

The method SAW clearly demonstrates the idea of integrating the values and weights of criteria into a single estimating value - utility function of the method:

$$
S_{k}=0.3 \cdot D R P_{k}+0.2 \cdot I U A_{k}+0.3 \cdot M P L_{k}+0.2 \cdot D C C_{k},(4)
$$

where $S_{k}$-weighted estimation of the $k^{t h}$ locality; $D R P_{k}, I U A_{k}, M P L_{k}, D C C_{k}-$ transformed values (density of rural

population, intensity of urban areas, the market price of the land, distance to the city center respectively) of the $k^{\text {th }}$ locality.

Calculations using SAW utility function (6) have been performed on the basis of transformed values applying all three

transformation formulas.

Transformation procedures and the MCDM methods influence the evaluation of the localities. It is stated in the theory of the multicriteria analysis that there is not one method that would be suitable for all the cases, therefore, it is worthy to calculate using different methods. This article employs SAW and Data Envelopment Analysis (DEA) in which the so-called utility function is constructed differently.

\section{DEA method}

DEA method (Farrell, 1957; Charnes et al., 1978; Coelliet et al., 2005; Charnes et al., 2013) is a technique for measuring the relative efficiency of decision making units (DMUs) that use similar inputs to produce similar outputs where the multiple inputs and outputs are incommensurate in nature. By this method the efficiency of each locality is evaluated with respect to the best localities in practice.

Criteria the higher values of which are considered to be better in terms of evaluation are called results (outputs). For example, in this study, a relatively higher density of rural residents is more subsistent for suburban areas. Criteria the lower values of which are considered to be better in terms of evaluation are called resources (inputs). For example, a relatively shorter distance to the city center is beneficial for the formation of suburban areas. Therefore, the criteria of density of rural residents, intensity of urbanized territories, and market price of land were assigned to the group of results (outputs), and distance to the city center was assigned to the group of resources (inputs). Hence, DEA method in our case deals with the space of one input and three outputs.

To avoid weak discriminating power of DEA linear programing models the idea of efficiency evaluation was realized using two-dimensional space and pair-wise comparison. The particular pairs of criteria are analyzed, e.g., the pair of criteria - distance to the city center, i.e., the distance, and intensity of the urbanized areas, i.e., the intensity. Standardized values of the criteria are used, i.e., $r_{i j} \in[0 ; 1]$. The efficiency of the intensity of urban areas for the $k^{t h}$ locality $\left(E_{k}(I U A)\right)$ is calculated using the proportion of the real intensity of the locality to the practically best possible intensity (i.e., to the highest value, because the intensity is assigned to the group of results), while the distance remains the same. The efficiency of the distance to the city center for the $k^{\text {th }}$ locality $E_{k}(D C C)$ is calculated using the proportion of the practically possible shortest distance (because the distance is assigned to the group of results) to the real distance of the locality with respect to the same level of intensity. By using this method, the efficiencies in all possible pairs of criteria are calculated and then the general weighted efficiency of the locality is estimated:

$$
E_{K}=0,3 \cdot E_{k}(D R P)+0,2 \cdot E_{k}(I U A)+0,3 \cdot E_{k}(M P L)+0,2 \cdot E_{k}(D C C),
$$

The evaluations of efficiency were calculated for all the localities in the same manner. Hence, according to the multi-criteria analysis of the suburban localities, the problem of the exclusion of suburban areas was solved. Generally speaking, MCDM method provides a possibility to process simultaneously two types of information: objective information (evaluation matrix) and subjective information (the priority-weight, given to each criterion). It must be stressed the MCDM method does not perform optimization. It simply identifies a set of ranked preferences by assigning concise scores to each alternative. This final score assignment is performed by calculations with respect to both, objective and subjective standpoints. The alternative having the higher score is not the "best". It is the one that gets the best compromise when all the criteria are simultaneously considered. This was also reflected in the obtained results of the evaluation.

Therefore, the suburban areas were excluded by summarizing the results of all used methods of the multicriteria analysis. By using different methods, the calculations with different values were made and the summative method was used for the exclusion of areas. All the evaluations that were made using the aforementioned methods are sorted in 
ascending order. The summative (integral) function $F(x)$ was formed. The function $F(x)$ was nominated using the division of the highest cumulative value, because the integral (distributional) function has to meet the requirement of $0 \leq F(x) \leq 1$ (Figure 1).

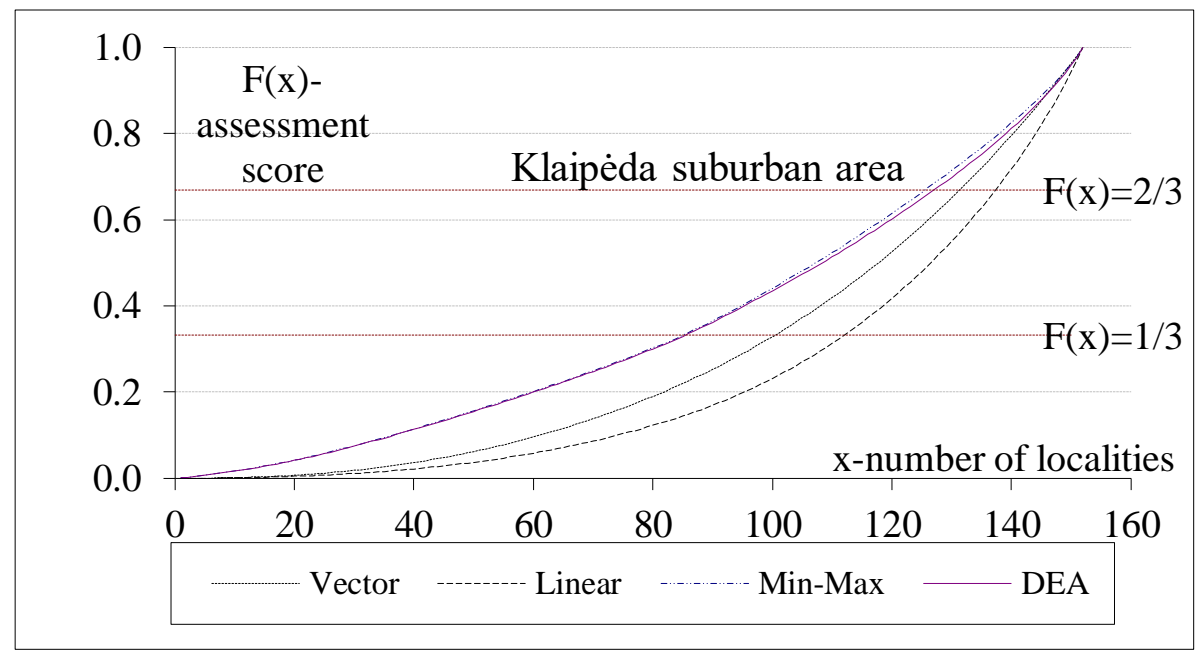

Figure 1. Cumulative distribution functions formed by MCDM methods results

The distribution function is divided into three equal intervals: $[0 ; 1 / 3],[1 / 3 ; 2 / 3],[2 / 3 ; 1]$. The locality that has the value that falls into the first interval $[0 ; 1 / 3]$, second interval $[1 / 3 ; 2 / 3]$, and third interval $[2 / 3 ; 1]$ is considered to be an unfavorable, moderately favorable, and highly favorable suburban area, respectively. After the selection of the localities, the localities that were mentioned two times or more out of the four possible times in the partial lists were included in the final list of favorable suburban areas. In the same manner, the unfavorable areas for suburban localities were listed. The localities that did not fall into the lists of highly favorable and unfavorable were assigned to moderately favorable. Hence, according to the results, three suburban areas of the cities were distinguished according to the intensity of urban development. The localities that fall into the evaluation of the most favorable suburban area were assigned to area I. Moreover, area II comprises the localities that have the moderate evaluation, and the localities of the most unfavorable evaluation were assigned to area III.

The territories in the distinguished suburban areas were analyzed according to the structure of lands that reflects the impact of a man on the landscape and the urbanization extent of the territory. During the analysis, lands were categorized in three groups:

- $\quad$ Built-up areas (land occupied by buildings or required for their exploitation, yards, squares)

- Agricultural land

- Natural or relatively natural areas (forests, swamps, plantations of trees and bushes, and water bodies).

During the analysis of the land structure of the rural localities of the distinguished areas, the intensity of indicators that affect the development of residential areas were indicated: the distance to the city, population size, and the size of residential area.

\section{RESULTS AND DISCUSSION}

\section{Evaluation of the urban impact areas}

According to the multicriteria analysis method described in the methodology, the areas of the urban development impact were identified, i.e., 583 villages from agricultural areas fall into this category. Besides them, 71 villages that comprise more than $70 \%$ of forests, swamps, and other natural or relatively natural lands (which are included in the forested rural landscapes) are in the urban development area. According to the results of the multicriteria analysis, the suburban areas according to the intensity of the urban development in the range of municipality were categorized into three groups. It was ascertained that area I, area II, and area III have 12 settlements, 33 settlements, and 163 rural residencies in Kaunas district, respectively. In Vilnius district, area I, area II, and area III have 28 settlements, 80 settlements, and residencies, respectively. In Klaipeda district, area I, area II, and area III have 18 residencies, 35 settlements, 99 rural residencies, respectively. The summarized results for the suburban areas of Kaunas, Vilnius, and Klaipeda cities are given in Figures 2, 3, and 4. 


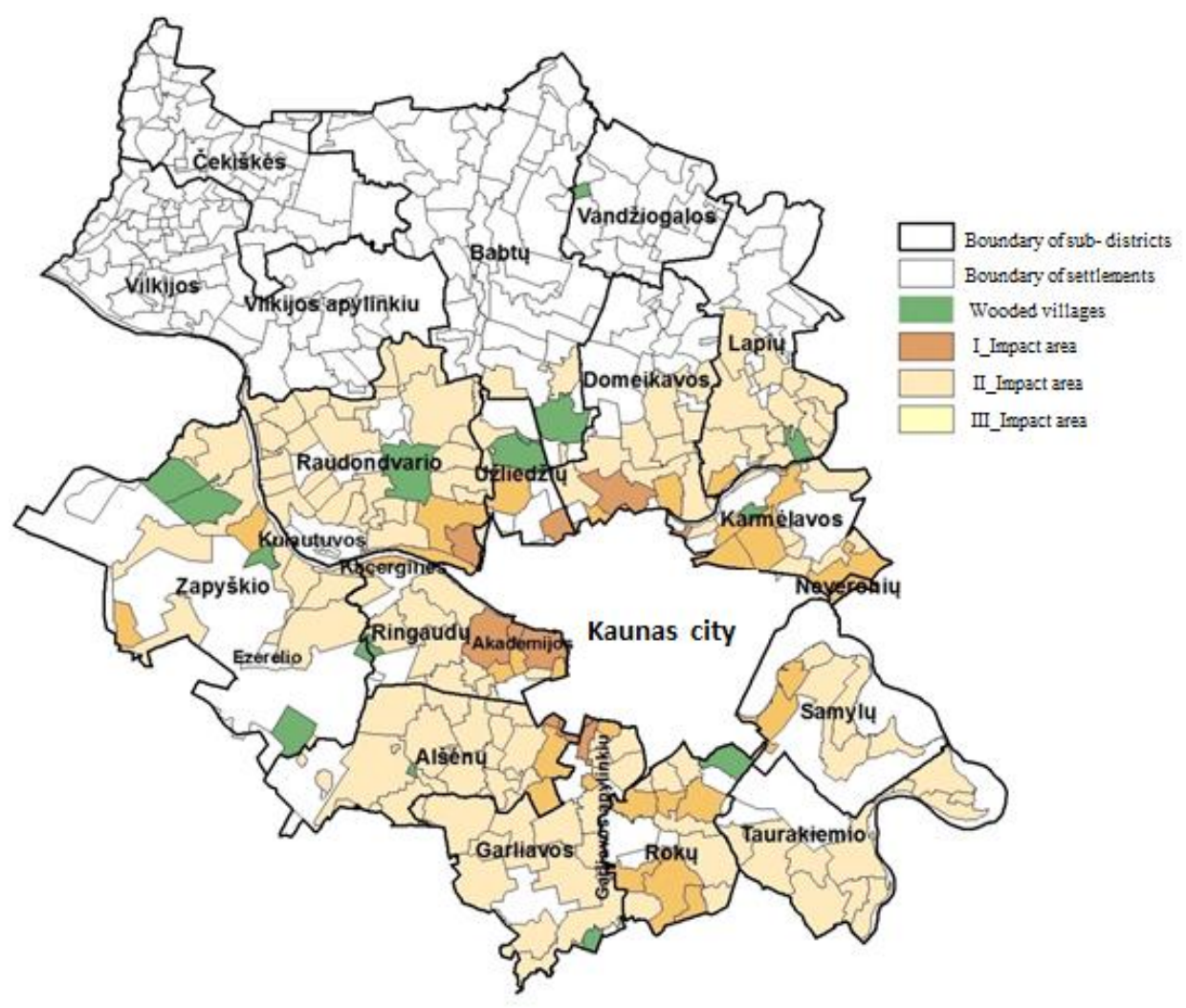

Figure 2. Urban development impact areas of Kaunas city

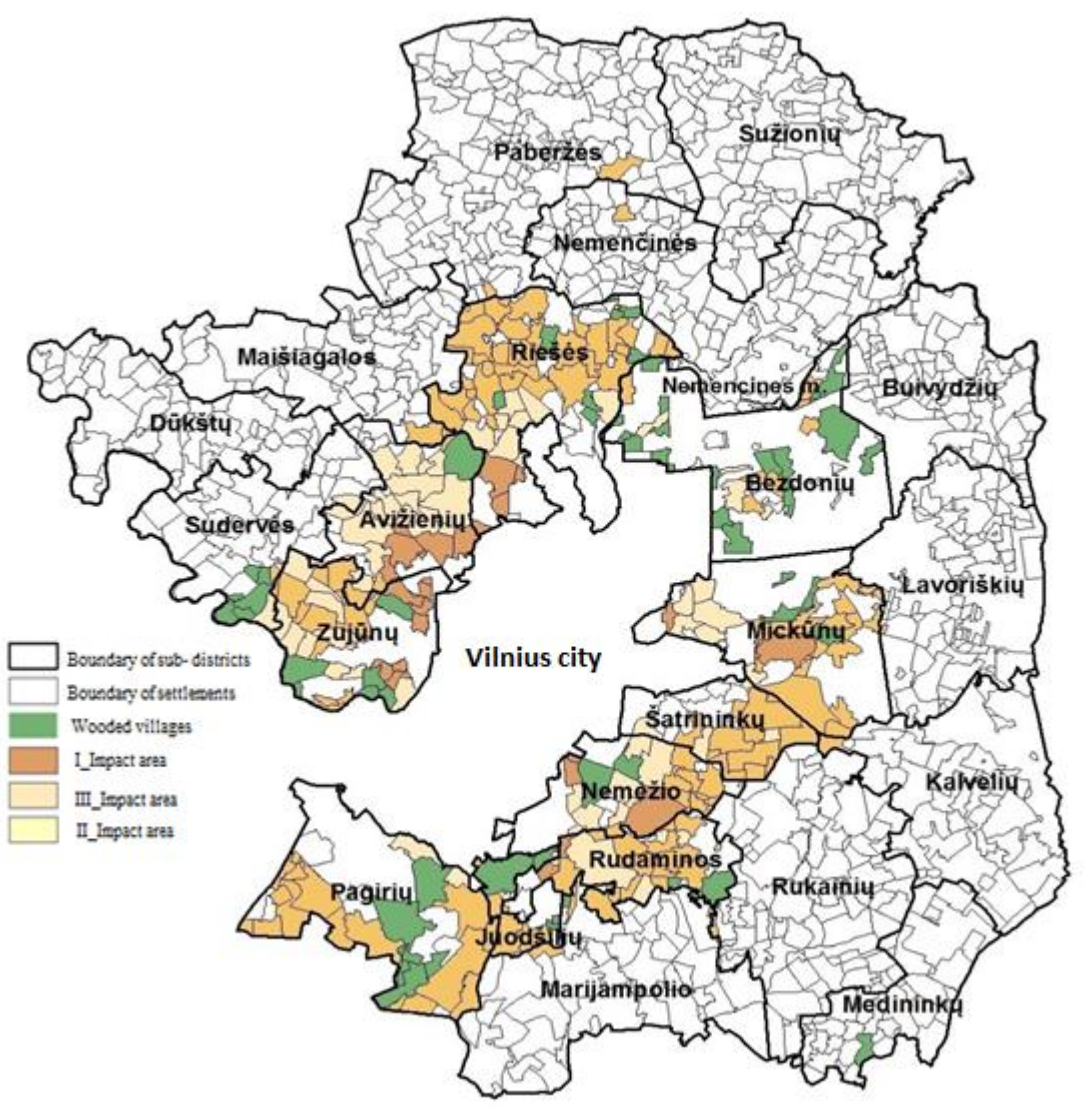

Figure 3. Urban development impact areas of Vilnius city 


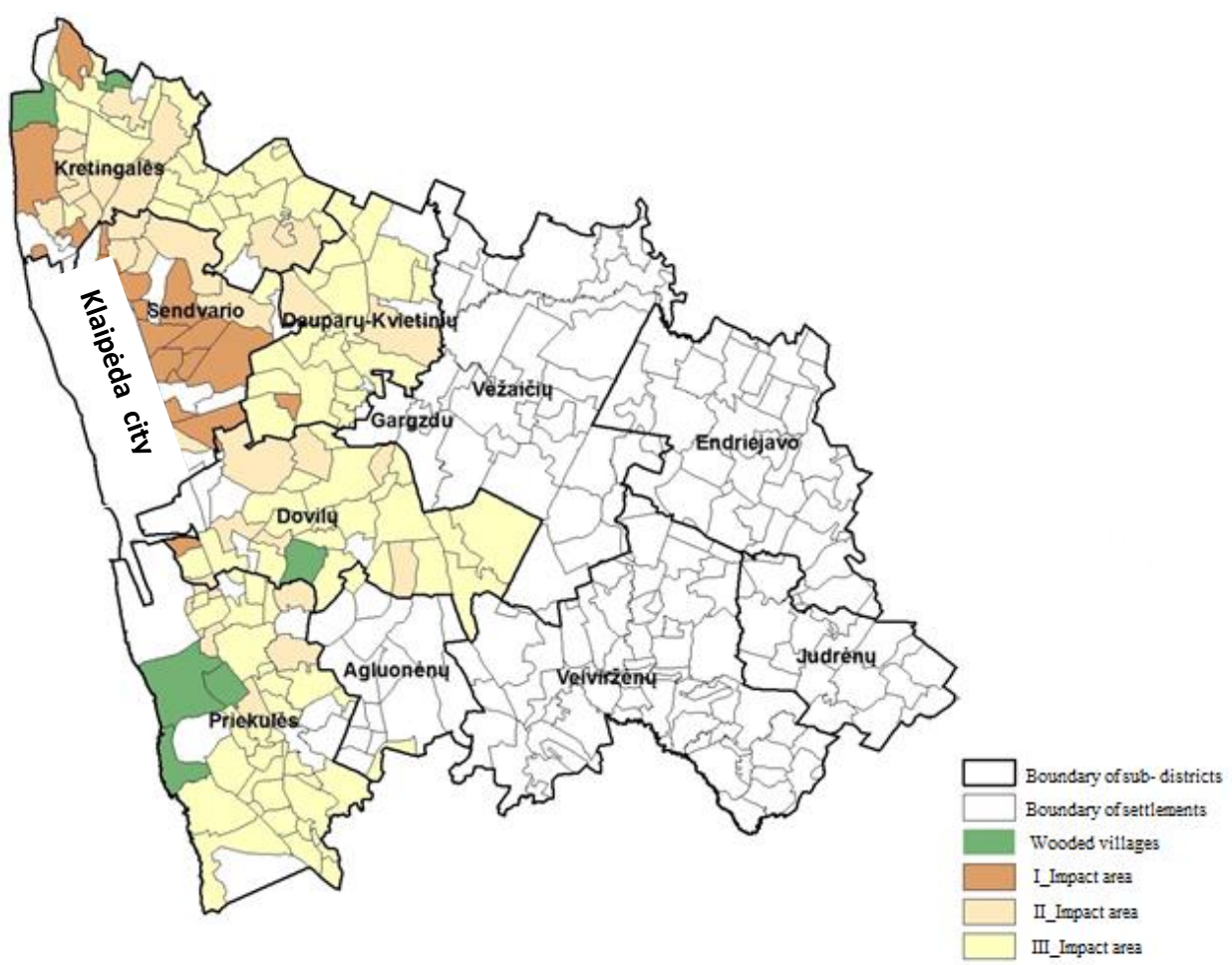

Figure 4. Urban development impact areas of Klaipeda city

Structure and transformation processes of agricultural landscape were analyzed in the three distinguished areas.

Structural research of agricultural landscape in suburban areas

Problems of territorial planning and development of suburban areas are relevant in countries with large urban agglomerations. However, methods of territorial planning applied by foreign states are mostly designed not to adapt nonagricultural areas for specialized farming but to rationally harmonize the layout of urban areas and green spaces (Gordon \& Richardson, 2000; Hayden, 2004; Lay Ong, 2003; Neuman, 2000; Powell, 2000; Schrijnen, 2000; Steenberger, 1996). According to J. Bucas (2010), orderly managing agriculture in each public formation the rural landscape was primarily transformed (restructured) and then consistently formed, i.e., its evolution took place in leaps. During the period of consistent formation new elements adapted to the environment, the rural landscape functionally and compositionally improved, acquiring a distinctive architectural character. The conducted research usually considers changes of relatively stable elements of landscape or of their influencing phenomena, and their intensity.

The agricultural landscape of suburban areas can be characterized by three main structural components reflecting the distribution of relatively stable, low-changing lands. This is a built-up area (most affected by a man due to urban development), agricultural lands (plots adapted for agricultural purposes), and forests and other land (the least affected natural or relatively natural lands). Due to the impact of urban development, the structure of these components is altered, mainly by reducing the agricultural lands.

On an average, the built-up area and roads in agricultural land of Lithuanian rural territories comprise $2.1 \%$ of the total area. Moreover, in the area under the influence of Vilnius city, this rate is significantly higher: in residential areas, up to $10 \mathrm{~km}$ away from the center of Vilnius city it reaches $29.8 \%$, from 10.1 to $15 \mathrm{~km}$ its is $18.1 \%$, from 15.1 to $20 \mathrm{~km}$ it is $11.0 \%$, and from 20.1 to $25 \mathrm{~km}$ it is $11.4 \%$. Built-up areas reach 0.15 ha per single villager. This rate is the lowest in suburban areas and towns (an average of $0.07 \mathrm{ha}$ ) and is the largest in villages with individual farms ( $0.62 \mathrm{ha}$ ).

By analyzing the urban development in the agricultural land, it was assumed that the growth of residential areas in suburban territories is determined not by the worthiness of nonagricultural land and forests but rather by economic criterial and the priority given to this area for one or another activity.

The largest impact of urban development on the agricultural landscape is observed in areas closest to the major cities. Away from the city, the density of rural population, the built-up areas, and the average market value of land are receding (Table 2).

The agricultural area intensively affected by urban development in Vilnius, Kaunas, and Klaipeda regions on average comprises $8.3 \%$ of suburban neighborhoods, of which moderately affected are $22.1 \%$, and little affected $63.6 \%$.

Assuming that the urban area depends on the population density $\left(\mathrm{X}_{1}\right)$ in the area, the distance of villages from the city $\left(\mathrm{X}_{3}\right)$ and the size of residential area $\left(\mathrm{X}_{2}\right)$, a paired and multiple correlation analysis among all three given factors was performed. 
Table 2. Characteristics of urban development impact areas in agricultural areas of suburban neighborhoods of Vilnius, Kaunas, and Klaipèda districts

\begin{tabular}{|c|c|c|c|}
\hline Factors & Vilnius district & $\begin{array}{r}\text { Kaunas } \\
\text { district }\end{array}$ & Klaipèda district \\
\hline \multicolumn{4}{|c|}{ Urban Development Impact Area I } \\
\hline Area, ha & 4783.2 & 2679.4 & 4720.6 \\
\hline \multicolumn{4}{|l|}{ Distance from the city center to village(s), $\mathrm{km}$ : } \\
\hline average & 12.3 & 10.0 & 8.2 \\
\hline maximum & 17.4 & 12.6 & 19.6 \\
\hline Density of rural population per $1 \mathrm{~km}^{2}$ in 2001 & 416 & 655 & 68 \\
\hline Built-up areas in percent & 31.3 & 38.8 & 15.0 \\
\hline $\begin{array}{l}\text { Average market value of land designated for agricultural purposes, } \\
\text { thousand EUR/ha }\end{array}$ & 182.8 & 70.1 & 94.7 \\
\hline \multicolumn{4}{|c|}{$\begin{array}{ll}\text { Urban Development Impact Area II }\end{array}$} \\
\hline Area, ha & 12439.0 & 8996.7 & 10915.4 \\
\hline \multicolumn{4}{|l|}{ Distance from the city center to village(s), $\mathrm{km}$ : } \\
\hline average & 16.0 & 14.8 & 15.0 \\
\hline maximum & 30.7 & 24.3 & 27.4 \\
\hline Density of rural population per $1 \mathrm{~km}^{2}$ in 2001 & 114 & 171 & 36 \\
\hline Built-up areas in percent & 12.9 & 17.8 & 11.1 \\
\hline $\begin{array}{l}\text { Average market value of land designated for agricultural purposes, } \\
\text { thousand EUR/ha }\end{array}$ & 126.6 & 39.4 & 53.3 \\
\hline \multicolumn{4}{|c|}{ Urban Development Impact Area III } \\
\hline Area, ha & 22798.5 & 48341.8 & 30659.2 \\
\hline \multicolumn{4}{|l|}{ Distance from the city center to village(s), $\mathrm{km}$ : } \\
\hline average & 19.9 & 18.6 & 21.6 \\
\hline maximum & 35.6 & 30.4 & 33.2 \\
\hline Density of rural population per $1 \mathrm{~km}^{2}$ in 2001 & 48 & 36 & 29 \\
\hline Built-up areas in percent & 6.1 & 8.4 & 6.1 \\
\hline $\begin{array}{l}\text { Average market value of land designated for agricultural purposes, } \\
\text { thousand EUR/ha }\end{array}$ & 59.1 & 7.8 & 6.7 \\
\hline
\end{tabular}

The results of multiple correlation reveal that factors mentioned in individual suburban areas influence the degree of urbanization of the territory by $24 \%-31 \%$ (Table 3 ).

Table 3. Factors of dependence on the built-up area (Y), population density $\left(\mathrm{X}_{1}\right)$, average size of residential area $\left(\mathrm{X}_{2}\right)$, and distance from villages to the city center $\left(\mathrm{X}_{3}\right)$ in Vilnius, Kaunas, and Klaipeda districts

\begin{tabular}{llccc}
\hline District & \multicolumn{1}{c}{ Equation of multiple regression } & $\begin{array}{c}\text { Correlation } \\
\text { coefficient } \mathbf{r}\end{array}$ & $\begin{array}{c}\text { Determination } \\
\text { coefficient } \mathbf{R}^{2}\end{array}$ & $\begin{array}{c}\text { Reliability } \\
\text { index } \\
\mathrm{t}\end{array}$ \\
\hline Vilnius & $\mathrm{Y}=25.22+0.0345 \mathrm{x}_{1}-1.04 \ln \mathrm{x}_{2}-4.3 \ln \mathrm{x}_{3}$ & 0.495 & 0.245 & $\mathrm{t}>80 \%$ \\
\hline Kaunas & $\mathrm{Y}=34.1+0.0115 \mathrm{x}_{1}+229.5 / \mathrm{x}_{2}-8.71 \ln \mathrm{x}_{3}$ & 0.517 & 0.268 & $\mathrm{t}>99 \%$ \\
\hline Klaipe்da & $\mathrm{Y}=19.68+\ln 3.98 \mathrm{x}_{1}-2.79 \ln \mathrm{x}_{2}-0.31 \mathrm{x}_{3}$ & 0.565 & 0.320 & $\mathrm{t}>99 \%$ \\
\hline All 3 districts & $\mathrm{Y}=38.42+0.0167 \mathrm{x}_{1}-1.86 \ln \mathrm{x}_{2}-6.63 \ln \mathrm{x}_{3}$ & 0.450 & 0.203 & $\mathrm{t}>99 \%$ \\
\hline
\end{tabular}

The fact that the degree of urbanization is mainly determined not by the population density or distance from the city but rather by other factors (such as comfortable roads, objects of infrastructure, conditions for planning, and building) can be explained by the fact that suburban territories in residential areas were historically formed and developed not by the former boundaries of villages by rather by priorities expressed in the territorial planning documentation.

In order to determine to what extent the agrarian landscape was affected by the urban impact, the structure of lands was compared in each rural area. The land areas were categorized as follows: 1) built-up land; 2) areas mastered by a man for agricultural activities (relatively called agricultural land although containing other lands, the outlines of which were not expressed in a small-scale map); 3) areas little affected by a man (the rest of the land, which mainly consists of forests, including swamps, bushes, and other natural or relatively natural lands). It was determined that due to the impact of urban development the structure of these components has altered mainly by reducing the agricultural lands. The largest changes are observed in Vilnius region where the percentage expression of agricultural lands in area I is by $34 \%$ lower than in area III, and in Kaunas region where the percentage expression of agricultural lands in area I is by $79 \%$ lower than in area III (Table 4).

According to the latest general agricultural census, the area of agricultural lands used in Vilnius, Kaunas, and Klaipedda districts decreased by an average of $4.2 \%$ (to compare in Lithuania it increased by $7.2 \%$ ).

The research revealed that the change of agricultural landscape is mainly related to the reduction of agricultural lands. Therefore, while addressing the issues of formation of suburban landscapes, the following general significant requirements for the planning of landscape must be met, i.e., to optimize the ratio of natural, agricultural and urban areas, the territorial structure of lands, land plots, and land holdings. Thus, in order to ensure the balanced 
impact of major urban development on the agricultural landscape, the average built-up area of major urban development should not exceed 20\%-30\%, and the area of agricultural lands should not be less than 30\%-45\%. In order to preserve fertile lands, the built-up areas should be designed on the land with lowest productivity.

Table 4. Structure of agricultural landscape in suburban neighborhoods of Vilnius, Kaunas and Klaipèda districts

\begin{tabular}{|c|c|c|c|c|c|c|c|c|}
\hline \multirow[t]{2}{*}{ Factors } & \multirow[t]{2}{*}{$\begin{array}{l}\text { Number } \\
\text { of villages }\end{array}$} & \multirow[t]{2}{*}{ Area ha } & \multicolumn{2}{|c|}{ Built-up area } & \multicolumn{2}{|c|}{ Agricultural lands } & \multicolumn{2}{|c|}{$\begin{array}{c}\text { Forests and other } \\
\text { lands }\end{array}$} \\
\hline & & & ha & percent & ha & percent & ha & percen \\
\hline \multicolumn{9}{|c|}{ Urban Development Impact Area I } \\
\hline $\begin{array}{l}\text { Neighborhoods of Vilnius } \\
\text { district }\end{array}$ & 27 & 4783,2 & 1495,3 & 31.3 & 2219,8 & 46.4 & 1068,1 & 22.3 \\
\hline $\begin{array}{l}\text { Neighborhoods of Kaunas } \\
\text { district }\end{array}$ & 12 & 2679,4 & 1041,3 & 38.8 & 971,9 & 36.3 & 666,2 & 24.9 \\
\hline $\begin{array}{l}\text { Neighborhoods of Klaipeda } \\
\text { district }\end{array}$ & 18 & 4720,6 & 706,9 & 15.0 & 3476,1 & 73.6 & 537,6 & 11.4 \\
\hline Total: & 57 & 12183,2 & 3243,5 & 26.6 & 6667,8 & 54.7 & 2271,9 & 18.7 \\
\hline \multicolumn{9}{|c|}{ Urban Development Impact Area II } \\
\hline $\begin{array}{l}\text { Neighborhoods of Vilnius } \\
\text { district }\end{array}$ & 74 & 12439,0 & 1604,5 & 12.9 & 7014,8 & 56.4 & 3819,7 & 30.7 \\
\hline $\begin{array}{l}\text { Neighborhoods of Kaunas } \\
\text { district }\end{array}$ & 31 & 8996,7 & 1602,8 & 17.8 & 5198,1 & 57.8 & 2195,8 & 24.4 \\
\hline $\begin{array}{l}\text { Neighborhoods of Klaipèda } \\
\text { district }\end{array}$ & 33 & 10915,4 & 1211,5 & 11.1 & 7000,7 & 64.1 & 2703,2 & 24.8 \\
\hline Total: & 138 & 32351,1 & 4418,8 & 13.7 & 19213,6 & 59.4 & 8718,7 & 26.9 \\
\hline \multicolumn{9}{|c|}{ Urban Development Impact Area III } \\
\hline $\begin{array}{l}\text { Neighborhoods of Vilnius } \\
\text { district }\end{array}$ & 144 & 22789,5 & 1403,7 & 6.1 & 14188,1 & 62.3 & 7197,7 & 31.6 \\
\hline $\begin{array}{l}\text { Neighborhoods of Kaunas } \\
\text { district }\end{array}$ & 149 & 48341,8 & 4061,7 & 8.4 & 31361,8 & 64.9 & 12918,2 & 26.7 \\
\hline $\begin{array}{l}\text { Neighborhoods of Klaipeda } \\
\text { district }\end{array}$ & 95 & 30659,2 & 1881,6 & 6.1 & 22729,3 & 74.1 & 6048,3 & 19.8 \\
\hline Total: & 388 & 101790,5 & 7347,0 & 7.2 & 68279,2 & 67.1 & 26164,2 & 25.7 \\
\hline $\begin{array}{ll}\text { Total in } & \text { suburban } \\
\text { neighborhoods: } & \end{array}$ & 583 & 146324,8 & 15009,3 & 10.3 & 94160,6 & 64.3 & 37154,8 & 25.4 \\
\hline
\end{tabular}

Note: the table exclude villages where forests and other natural lands comprise more than $70 \%$ of total area.

\section{CONCLUSION}

The landscape in suburban areas is affected by man more than any other area. With the increasing impact on the city, suburban areas are not completely built-up and their landscape is formed as the combination of urban and agricultural-rural landscape, where a relatively larger area is occupied by urban territories alongside lands designed for agricultural purposes as well as natural and relatively natural lands. In the agricultural areas of suburban neighborhoods of Vilnius, Kaunas, and Klaipeda districts, the built-up area comprises an average of $10.3 \%$ of the total area, agricultural lands comprise $64.3 \%$, and forests and other lands comprise $25.4 \%$. The agricultural area most intensively affected, moderately affected, and little affected by the urban development in Vilnius, Kaunas, and Klaipeda districts comprises an average of $8.3 \%, 22.1 \%$, and $63.6 \%$ of suburban neighborhoods, respectively. The largest impact of urban development on the agricultural landscape is observed in territories closest to the major cities (area category I), where the structure of agricultural landscape components is mainly altered by reducing the agricultural lands. Away from the city, the density of rural population, the built-up areas, and the average market value of land are receding.

In order to ensure a balanced impact of major urban development on the agricultural landscape, the average builtup area of major urban development should not exceed 20\%-30\% and the area of agricultural lands should not be less than $30 \%-45 \%$. In order to preserve fertile lands, the built-up areas should be designed lands with the lowest productivity.

\section{REFERENCES}

1. Adell G. 2016. Theories and models of the peri-urban interface: a changing conceptual landnscape. Strategic environmental planning and management of the periurban interface. Research Project: UCL-DPU. Available online: http://eprints.ucl.ac.uk/43/1/DPU_PUI_Adell_THEORIES_MODELS.pdf (accessed on 15/11/ 2016).

2. Andrews M. S. 1986. Suburbanization, Agricultural Productivity and Right to farm. NATIONAL Conference on Sustaining Agriculture Near Rities, 42-47, Boston.

3. Baumeister N. 2006. Neue Landschaftsarchitektur = New landscape architecture: Germany, Austria, Switzerland.

4. Berger A. 2006. Drosscape: Wasting Land in Urban America. New York: Princeton Architectural Press.

5. Bucas J. 2005. Lietuvos kraštovaizdžio vizija. Kaunas. (In Lithuanian) 
6. Bucas J. 2010. Miesto drieka kaime: socialinis ir aplinkosauginis aspektai. Lietuvos urbanistinis forumas. Urbanistine drieka: miesto ir kaimo sandūra. 5-11.(In Lithuanian)

7. Cesnavicius D. 1999. Didžiujų Lietuvos miestų priemiestinių zonų žemės naudojimo geografiniai ypatumai (Vilniaus ir Klaipėdos priemiesčių pavyzdžiu): daktaro disertacija. Geografijos institutas, Vilniaus pedagoginis universitetas.

8. Cesnulevicius A., Lupickaite, R., Jureviciene, I. 2005. Žemėnaudos struktūros kaita ir jos ịtaka agrarinių kraštovaizdžių geodinaminiam stabilumui (Skiemonių seniūnijos pavyzdžiu). Geografijos metraštis, Nr. 38 (1), 80-89. (In Lithuanian)

9. Chang C. W., Wu C. R., Lin C. T., Chen H. C. 2007. An application of AHP and sensitivity analysis for selecting the best slicing machine. Computers \& Industrial Engineering, Vol. 52, pp. 296-307. https://doi.org/10.1016/j.cie.2006.11.006

10. Charnes A., Cooper W. W., Lewin A. Y., Seiford L. M. 2013. Data envelopment analysis: Theory, methodology, and applications. Dordrecht: Springer Science \& Business Media.

11. Charnes A., Cooper W.W., Rhodes, E. 1978. Measuring the Efficiency Of Decision Making Units, European Journal of Operational Research, Vol. 46, pp. 185-200.

12. Charter of the new Urbanism. Congress for the new urbanism. Available online: http://www.cnu.org/charter (accessed on 15/11/2016).

13. Chen S.Y. 2009. Identifying and prioritizing critical intellectual capital for e-learning companies. https://doi.org/10.1108/09555340910986664

14. Clawson M. 1971 Suburban land Conversion in the U.S. Baltimore.

15. Coelliet T.J., Rao D.P., O'Donnell C.J., Battese G.E. 2005. An Introduction to Efficiency and Productivity Analysis, Springer.

16. Cowan R. 2005. The dictionary of urbanism. UK, Tisbury: Streetwise press.

17. Daujotaite J. 1967. Vilniaus priemiestinès zonos išplanavimas ir miesto apželdinimo perspektyva. Miestu ir gyvenviečiu apželdinimas, Vilnius, pp. 55-66. (In Lithuanian)

18. Daunora Z. J. 2003. Priemiesčio teritorijų planavimo sąlygos ir galimybès. Urbanistika ir architektūra, Nr. 27 (2), pp. 51-63. (In Lithuanian)

19. Daunora Z. J. 2010. Tvarumo ir darnos veiksniai planuojant urbanistinę plètrą. Urbanistika ir architektūra, Nr. 34 (4), pp. 208-215. (In Lithuanian) https://doi.org/10.3846/tpa.2010.20

20. Dijokiene D. 2006. Vilniaus istorinių priemiesčiu genezès, raidos ir vertybių ypatumai. Urbanistika ir architektūra, Nr. 30 (2), pp. 78-86. (In Lithuanian)

21. Farrell M.J. 1957."The Measurement of Productive Efficiency". Journal of the Royal Statistical Society, Vol. 120, pp. $253-281$. https://doi.org/10.2307/2343100

22. Figueira J., Roy B. 2002. Determining the weights of criteria in the ELECTRE type methods with a revised Simos' procedure. European Journal of Operational Research, Vol. 139, pp. 317-326. https://doi.org/10.1016/S0377-2217(01)00370-8

23. Hwang C., Yoon K. 1981. Multiple attribute decision making: Methods and applications, A state of the art survey. New York, NY: Sprinnger-Verlag. https://doi.org/10.1007/978-3-642-48318-9 3

24. Frey H. 2007. Compact, Decentralised or What? The Sustainable City debate, in The urban designer reader. M. Larice, E. Macdonald (Eds.). London: Routledger, pp. 328-343.

25. Gordon P., Richardson, H. W. 2000. Defending suburban sprawl, The Public Interest/Spring.

26. Hall P. 2002. Cities of tomorrow: an intellectual history of urban planning and design in the twentieth mentury. Blackwell.

27. Hayden D. 2004. A field guide to Sprawl. New York; London: W. W. Norton and Company Ltd.

28. Hoggart K., Buller H., Black R. 1995. Rural Europe: Identity and Change. London.

29. Hornis W., Van Eck J. R. 2008. A typology of peri-urban areas in the netherlands. Tijdschrift voor Economische en geografie, Vol. 99 (5), pp. 619-628. https://doi.org/10.1111/j.1467-9663.2008.00497.x

30. Ilbery B. 1998. The geography of rural change. London.

31. Jackson K. T. 1985. Crabgrass Frontier: The Suburbanization of America. Oxford.

32. Juskevicius P. Gauce K. 2010. Urbanistinio planavimo deformacijos. Urbanistika ir architektūra, No. 34 (4), pp. 195-207. (In Lithuanian) https://doi.org/10.3846/tpa.2010.19

33. Juskevicius P., Mozuriunaite S., Motieka S. 2009. Lietuvos urbanistinių sistemų transformacijos ir mutacijos. Urbanistika ir architektūra, Nr. 33 (4), pp. 225-238. (In Lithuanian) https://doi.org/10.3846/13921630.2009.33.225-238

34. Yoon K., Hwang, C.L. 1995. Hwang. Multiple Attribute Decision Making: An Introduction. Sage Publications, Thousand Oaks, CA. https://doi.org/10.4135/9781412985161

35. Laukaityte-Malzinskiene G. 2005. Priemiestinio kraštovaizdžio vertinimo ypatumai. Urbanistika ir architektūra, Nr. 29 (2), pp. 81-89. (In Lithuanian)

36. Lay Ong B. 2003. Green plot ratio: an ecological measure for architecture and urban planning. Landscape and urban planning, Vol. 63 (4), pp. 197-211. https://doi.org/10.1016/S0169-2046(02)00191-3

37. Masotti L. H. 1991. The Urbanization of the Suburbs. (ed). London.

38. Meeus, S. J. \& Gulinck, H. 2008. Semi-Urban areas in landscaoe research: A review, living reviews in landscape research Vol. 2(3), 1-45. https://doi.org/10.12942/lrlr-2008-3

39. Methods of Environmental Impact Assessment. London; New York: Spon Press, 2001. Available online:http://www.evtfuto.com/download/Other\%20Links/Methods\%20of\%20Environmental\%20Impact\%20Assessment\%20(2 ).pdf (accessed on 15/11/2016).

40. Mumford L. 1968. The city in history: its prigins, its transformations, and its prospects. Parvest Books. 
41. Neuman M. 2000. Regional design: Reccovering a great landscape architecture and urban planning tradition. Landscape and Urban Planning, Vol. 47, Iss. 3-4, pp. 115-128.

42. Powell K. 2000. City Transformed: Urban Architecture at the Beginning of the 21st Century. London: Laurence King.

43. Saaty T. L. 1980. The analytic hierarchy process: Planning, priority setting, resources allocation,New York, NY: McGraw.

44. Salminen P.; Hokkanen J.; Lahdelma,R. 1998. Comparing multicriteria methods in the context of environmental problems. European Journal of Operational Research, Vol. 104, pp. 485-496. https://doi.org/10.1016/S0377-2217(96)00370-0

45. Schrijnen P. M. 2000. Infrastructure networks and red-green patterns in city regions, Landscape and Urban Planning, Vol. 48, Iss. 3-4, pp. 191-204. https://doi.org/10.1016/S0169-2046(00)00042-6

46. Steenberger. 1996. Architecture and landscape: the design experiment or the great European garden and landscape. London.

47. Teaford J. C. 1995. Post-suburbia. New York.

48. Vaughan L., Griffiths L., Haklay M., Jones C.E. 2009. Do the suburbs exist? Discovering complexity and specificity in suburban buil form. Trans inst br geogr NS, Vol. 34, pp. 475-488. https://doi.org/10.1111/j.1475-5661.2009.00358.x

49. Voogd H. 1983. Multicriteria Evaluation for Urban and Regional Planning. Pion Limited, London, p.XIV+367

50. Wiese, A. 1997. Suburbia. Middle Class to the Last? Journal of Urban History, Vol. 26 (6), pp. 750-759. https://doi.org/10.1177/009614429702300605

51. Witherick M.; Ross S.; Small J. 2001. A modern dictionary of geography. 4th Editon. London: Arnold.

52. Zagorskis J. 2005. Miestų plètra ir poreikis priemiestinėms zonoms. Lietuvos kraštovaizdžio vizija: konferencijos pranešimų medžiaga, 115-122. (In Lithuanian)

53. Zavadskas E. K., Antucheviciene, J. 2007. Multiple criteria evaluation of rural building's regeneration alternatives. Building and Environment, Vol. 42, pp. 436-451. https://doi.org/10.1016/j.buildenv.2005.08.001

54. Zavadskas E. K., Kaklauskas, A. 1996. Multicriteria Evaluation of Building (Pastatų sistemotechninis įvertinimas). Vilnius: Technika. 